University of Nebraska - Lincoln

DigitalCommons@University of Nebraska - Lincoln

Journal of Women in Educational Leadership

Educational Administration, Department of

$10-2009$

\title{
Journal of Women in Educational Leadership
}

Marilyn Grady

University of Nebraska - Lincoln, mgrady1@unl.edu

Sharon Hoffman

University of Louisiana at Lafayette, sharichoffman@gmail.com

Joseph L. Eckenrode

University of Nebraska- Lincoln

Jean M. Haar

Minnesota State University, jean.haar@mnsu.edu

Follow this and additional works at: https://digitalcommons.unl.edu/jwel

Part of the Educational Administration and Supervision Commons

Grady, Marilyn; Hoffman, Sharon; Eckenrode, Joseph L.; and Haar, Jean M., "Journal of Women in Educational Leadership" (2009). Journal of Women in Educational Leadership. 249.

https://digitalcommons.unl.edu/jwel/249

This Article is brought to you for free and open access by the Educational Administration, Department of at DigitalCommons@University of Nebraska - Lincoln. It has been accepted for inclusion in Journal of Women in Educational Leadership by an authorized administrator of DigitalCommons@University of Nebraska - Lincoln. 


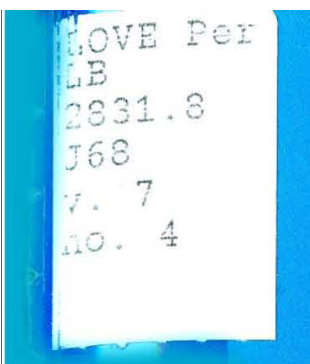

October 2009

VOLUME 7 ISSUE 4

ISSN 1541-6224

JOURNAL OF

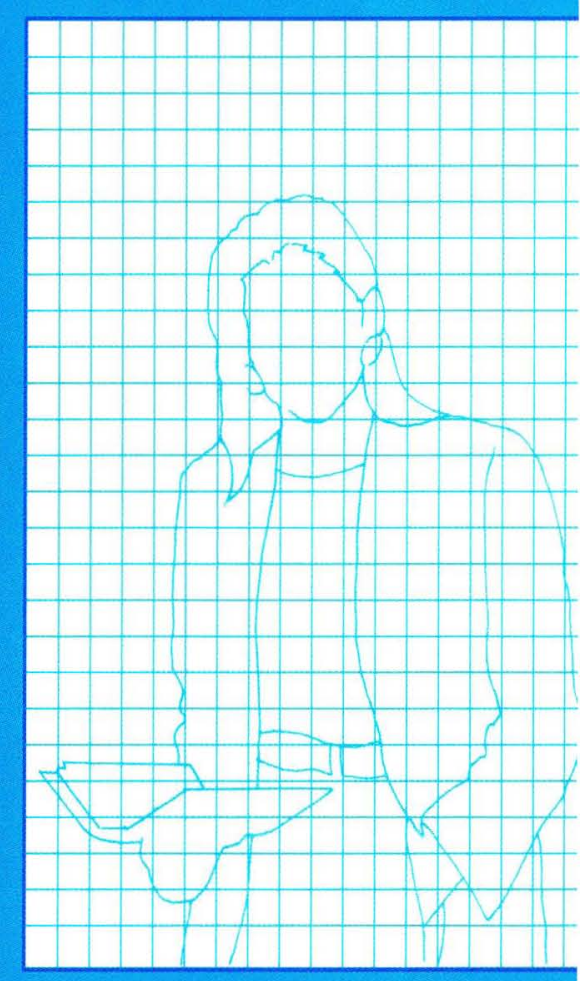

EADERSHIIP

Joninal of wonen in

educational leadership

Received on: 01-07-10

University of Nebraska,

Lincolin - Libraites 


\section{EDITOR}

Marilyn L. Grady, Ph.D.

University of Nebraska-Lincoln

\section{ASSOCIATE EDITOR}

Sharon C. Hoffman

Southeastern Louisiana University

MANAGING EDITOR

Joseph L. Eckenrode, Ph.D.

\section{BOOK REVIEW EDITOR}

Jean M. Haar, Ph.D

Minnesota State University-Mankato

\section{EDITORIAL BOARD}

Judith A. Aiken, University of Vermont Genevieve Brown, Sam Houston State University Miles T. Bryant, University of Nebraska-Lincoln Patti L. Chance, University of Nevada-Las Vegas Barbara K. Curry, University of Delaware Carla Edlefson, Ashland University Nancy Evers, University of Cincinnati Doreen Gosmire, University of South Dakota Jean M. Haar, Minnesota State UniversityMankato

Beverly Irby, Sam Houston State University Thomas L. Krepel, Northern Illinois University Linda L. Lyman, Illinois State University James E. Lyons, University of North CarolinaCharlotte
Martha McCarthy, Indiana University Martha N. Ovando, University of Texas-Austin Anita Pankake, University of Texas-Pan American Kaye Perry, New Mexico

Michael D. Richardson, Southeastern Louisiana University

Connie Ruhl-Smith, Bowling Green State University Trudy Salsberry, Kansas State University Charol Shakeshaft, Virginia Commonwealth University

Catherine Sielke, University of Georgia Marilyn Tallerico, Binghamton University Sandra F. Tonnsen, Western Carolina University Linda H. Wesson, University of Memphis

The JOURNAL OF WOMEN IN EDUCATIONAL LEADERSHIP (ISSN 1541-6224) Published quarterly January, A pril, July and October, one volume per year, by ProActive Publications, 439 North Duke Street, Lancaster, PA 17602-4967. POSTMASTER: Send address changes to Journal of Women in Educational Leadership, 439 North Duke Street, Lancaster, PA 17602-4967.

Subscriptions-Annual subscription $\$ 98.00$ per year for Institutional/Library; $\$ 69.00$ per year for Individual; $\$ 39.00$ per year for Student. Single copy price $\$ 24.00$.

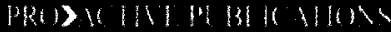

Protossional Bows for Actise ladbators
439 North Duke Street, Lancaster, PA 17602-4967 Website: www.proactivepublications.com

Copyright (C 2009 by ProActive Publicaitons. All Rights Reserved. 
Copyright (C) 2009

ProActive Publications

Lancaster, Pennsylvania USA

ISSN 1541-6224

Printed in the United States of America 